\title{
dental radiology
}

Editor:

JOHN W. PREECE, D.D.S.

American Academy of Dental Radiology

Department of Dental Diagnostic Sciences

School of Dentistry, The University of Texas Health Science Center at San Antonio

7703 Floyd Curl Dr.

San Antonio, Texas 78284

\section{Choice of contrast medium in sialography}

\author{
J. W. Verhoeven, Utrecht, The Netherlands \\ UNIVERSITY OF UTRECHT DENTAL SCHOOL
}

\begin{abstract}
Contrast media used for sialography were originally developed for other medical applications. Therefore, it was considered desirable to investigate the properties of these substances for use in sialography. Eleven radiopaque substances were selected, and their properties for sialography were studied. An in vitro study was made to determine their contrast qualities and their rate of evacuation after the sialographic examination. In animal experiments the possible harmful effects of the media on salivary gland tissues were studied. Moreover, the effects of the radiopaque material on the extraglandular tissues - which are important in understanding the consequences of spilling into these tissues - were investigated. The results of this study were compared with data from the literature. Conray 80, Amipaque 440, Lipiodol UF, Myodil, and Duroliopaque appear to be the media most suited for sialography, provided glandular overfilling is avoided. A prolonged clinical study is advised for a further selection from these agents.
\end{abstract}

Cont ly developed for the study of materials in general use for divided into oily media, water-soluble media, and suspensions. The literature regarding the properties and the side effects of these media in the indicated fields of application is very extensive (Tables I and II). However, the conclusions concerning side effects are sometimes contradictory.

The use of some of the media in sialography has resulted in many publications (Table II) in which the conclusions on side effects are also controversial. The literature is also incomplete, especially concerning some recently developed radiopaque materials. This diversity of opinions was the reason for the present investigation in which the properties of a number of contrast media, of potential use in sialography, are

From the Department of Oral Roentgenology (head: Prof. J. van Aken), the Department of Oral Surgery (head: Prof. Dr. P. Egyedi), and the Department of Oral Pathology (Dr. P. J. Slootweg). compared. The criteria for the evaluation of the contrast media were as follows:

1. The iodine salt concentrations before and after dilution with saliva should be sufficiently high.

2. The media should be eliminated rapidly from the healthy salivary gland after sialography. This property permits study of the glandular function and diminishes the risk of local side effects. It also makes possible the investigation of more than one gland during the same session.

3. The contrast media should have no harmful effects on the salivary gland tissue.

4. The media should be harmless in the event of spilling into the extraglandular tissues (fausse route).

\section{MATERIALS AND METHODS}

Information on the contrast media selected for this investigation is given in Tables I and II.

The iodine salt concentrations as given by the manufacturer or from the literature were checked radiographically. The iodine salt content was determined densitometrically from radiographs made from undiluted contrast medium samples by compar- 


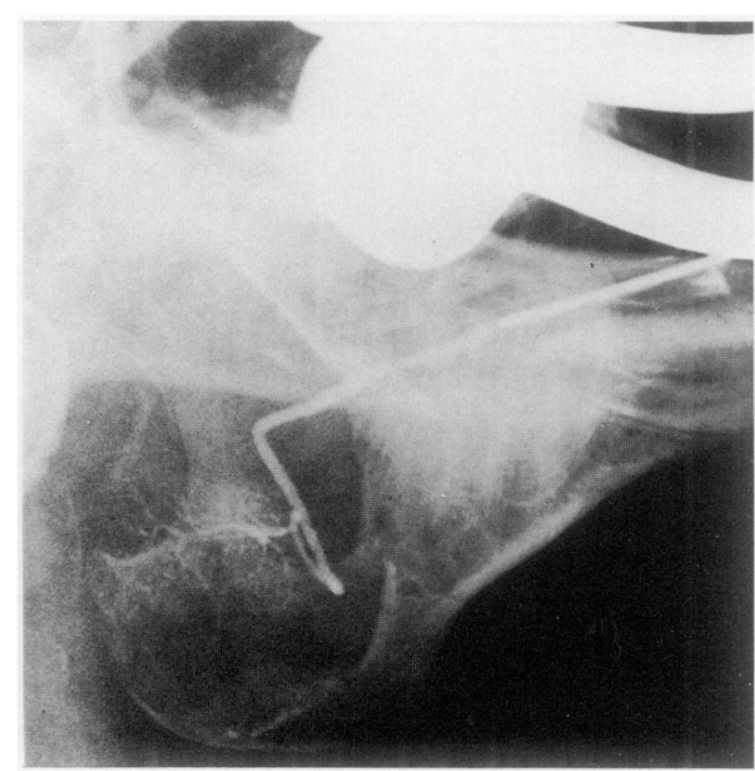

Fig. 1. Sialogram of a rabbit's submandibular gland; normal filling with $0.2 \mathrm{ml}$ of a water-soluble contrast medium.

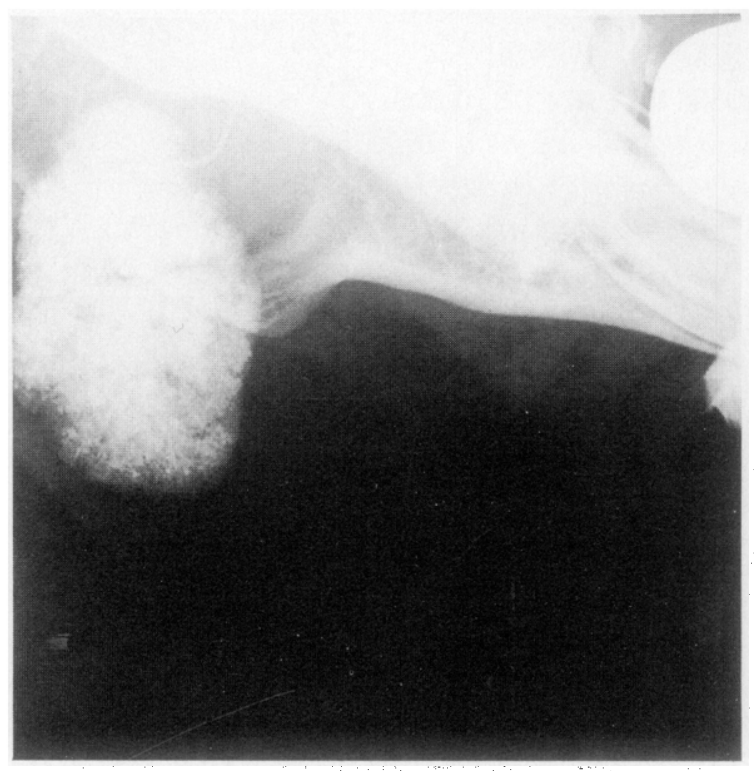

Fig. 2. Sialogram of a rabbit's submandibular gland; overfilling with $0.4 \mathrm{ml}$ of an oily contrast medium.

Table I

\begin{tabular}{|c|c|c|c|c|c|c|}
\hline \multirow[b]{2}{*}{ Product name } & \multirow[b]{2}{*}{ Generic name } & \multirow[b]{2}{*}{ Water soluble/oily } & \multicolumn{2}{|c|}{$m g l / m l$} & \multirow{2}{*}{$\begin{array}{l}\text { Viscosity (stated) } \\
\text { at } 37^{\circ} \mathrm{C} \text { in mPa.s }\end{array}$} & \multirow{2}{*}{$\begin{array}{c}\text { Osmolality } \\
\text { (stated) } \\
\text { at } 37^{\circ} \mathrm{C} \text { in } \\
\text { mmol/kg water }\end{array}$} \\
\hline & & & Stated & Measured & & \\
\hline Conray 80 & $\mathrm{Na}$-iothalamate & W & 480 & 478 & $8(37.5 \%)$ & 3,140 \\
\hline Isopaque 440 & $\mathrm{Na}(+\mathrm{Ca}+\mathrm{Mg})$-metrizoate & w & 440 & 442 & 6.6 & 2,640 \\
\hline Amipaque & Metrizamide & W & $440^{*}$ & 406 & 25.6 & 670 \\
\hline Urombrine 420 & Meglumine + Na-diatrizoate & W & 420 & 406 & $6-7$ & $1,885 \dagger$ \\
\hline Urografin $76 \%$ & Meglumine+Na-diatrizoate & W & 370 & 346 & 8.9 & 2,100 \\
\hline Endografin & Meglumine-iodipamide & W & 350 & 340 & 18.7 & 840 \\
\hline Hytrast & lopydol+iopydone & $W$ suspension & 500 & 470 & 600 & $\ldots .$. \\
\hline Dionosil oily & Propyliodone & O suspension & 340 & 382 & $1,250\left(?{ }^{\circ} \mathrm{C}\right)$ & - \\
\hline Lipiodol UF & Ethyl diiodostearate & $\mathrm{O}$ & 480 & 478 & 25 & - \\
\hline Myodil & Iophendylate & 0 & 384 & 370 & $?$ & $\cdots$ \\
\hline Duroliopaque & Ethyl monoiodostearate & $\mathrm{O}$ & 480 & 478 & 12 & $\ldots$ \\
\hline
\end{tabular}

* Powder and liquid volumes mixed according to the manufacturer's instructions for a solution containing $440 \mathrm{mg} I / \mathrm{ml}$

tOsmolarity in $\mathrm{mmol} / \mathrm{L}$ solution.

ing with potassium iodide solutions of known concentrations. A Joyce, Loebl \& Company double-beam recording microdensitometer was used for these and all other density measurements on the radiographs in this study.

Radiographs of a phantom model were made for the determination of the tendency of the contrast media to be diluted by saliva in a glandular duct. ${ }^{46}$ The phantom used to simulate a human head was composed of fourteen layers $(25 \times 25 \mathrm{~cm})$ of Plexiglas, each $1 \mathrm{~cm}$ thick, and four sheets of aluminum, each $0.1 \mathrm{~cm}$ thick. Along the film side of the phantom model, perpendicular to the x-ray beam, a polyethylene tube was placed in a horizontal position. The tube had an inner diameter of $2 \mathrm{~mm}$ and was comparable to a glandular duct of mean width.

Adjacent to the tube, an aluminum step-wedge (3-6-9-12-17 mm) was placed as reference object for densitometric measurements. The secretory pressure of a stimulated salivary gland was simulated by connecting one end of the tube to an open-ended 20 


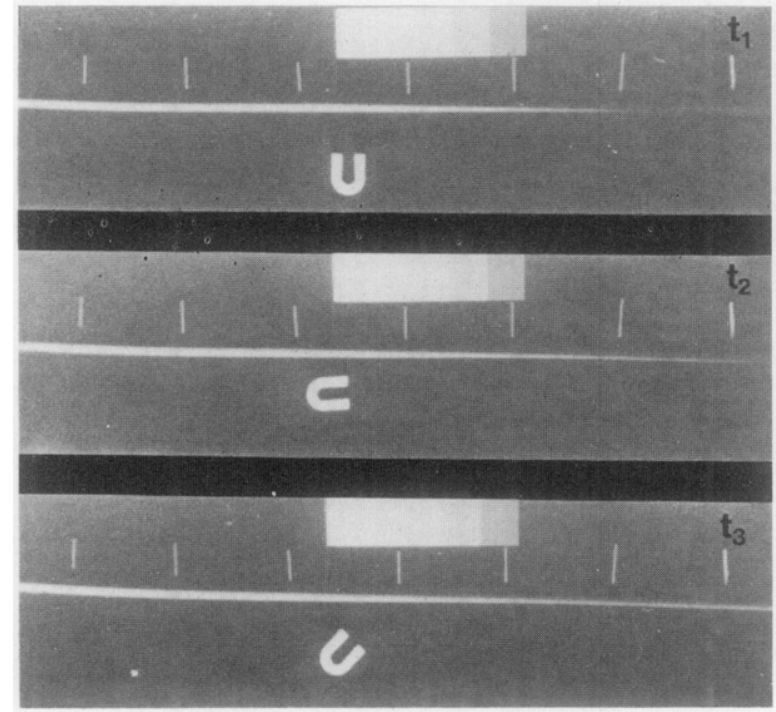

Fig. 3. Radiographs used for the study of contrast medium dilution with artificial saliva in a polyethylene tube. The radiographs were made immediately after the contrast medium instillation $\left(t_{1}\right)$ and $1\left(t_{2}\right)$ and $5\left(t_{3}\right)$ minutes later. Contrast medium: Urombrine 420 .

cc syringe placed $65 \mathrm{~cm}$ above the horizontal part of the tube in the phantom. ${ }^{47}$ This reservoir and tube system was filled with artificial saliva at a temperature of $37^{\circ} \mathrm{C}$. The composition of this artificial saliva is given in the appendix. The other end of the horizontal part of the tube was connected to a syringe filled with one of the selected contrast media at $37^{\circ} \mathrm{C}$. An amount of contrast medium sufficient to fill one half of the horizontal part of the tube was instilled in 30 seconds. Radiographs were obtained immediately after the instillation $\left(t_{1}\right)$ and 1 minute $\left(t_{2}\right)$ and 5 minutes $\left(t_{3}\right)$ later. The radiographs were processed under standardized conditions. Densitometric measurements were performed on nine predetermined positions along the tube's image. The density at each position was expressed in millimeters of aluminum equivalent of the step wedge. These values were compared with those from radiographs made of the same phantom after filling of the tube with undiluted iodine salt solutions of known concentration. This permitted the determination of the iodine salt concentration for all measuring points of the tube.

To study the evacuation of contrast media from a healthy salivary gland, the same Plexiglas aluminum phantom was used and a portion of the horizontal part of the tube lumen was narrowed to a diameter of $0.2 \mathrm{~mm}$ in order to simulate the finer glandular ducts

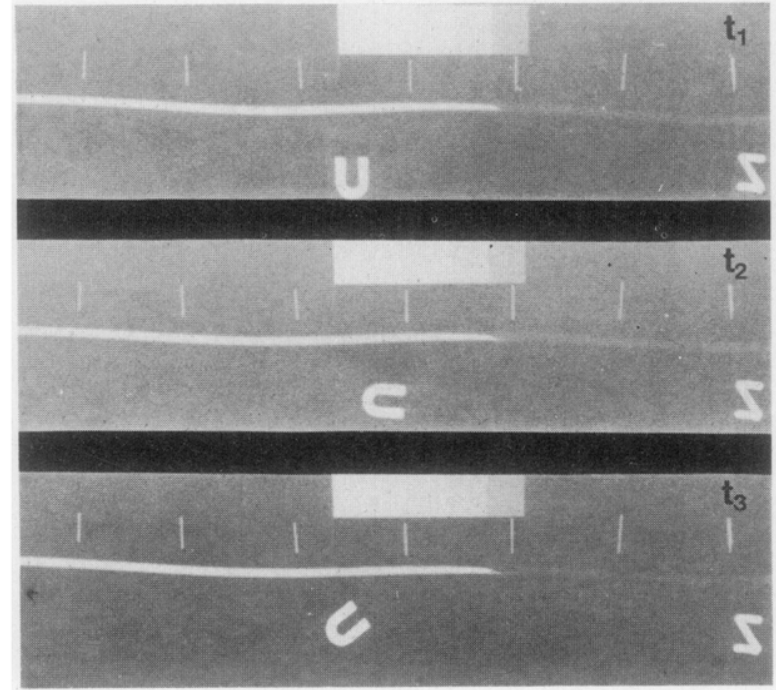

Fig. 4. See legend for Fig. 3. Contrast medium: Hytrast.

(Figs. 8 and 9). All other circumstances were the same as described above for the hydrostatic system. A volume of contrast medium sufficient to fill one half the length of the narrowed lumen was instilled $\left(37^{\circ} \mathrm{C}\right)$ and then the injecting syringe was removed and the tube end was left open. Radiographs were obtained immediately after removal of the syringe $\left(t_{1}\right)$ and 5 minutes later $\left(t_{2}\right)$. The films were processed under standardized conditions. The density of the tube image was measured at the place of instillation on all films, and the iodine salt concentration was determined as described above.

Animal experiments were conducted to study the local toxicity of the contrast media. All experiments described here were also performed with a physiologic saline solution for control purposes. Rabbits were selected for the study of the influence of radiopaque media on salivary gland tissue. Under general intravenous anesthesia (Nembutal), both submandibular glands of each rabbit were instilled with the same contrast material. One gland was filled with $0.2 \mathrm{ml}$ of the radiopaque material (normal volume), and the other side was overfilled by the instillation of $0.4 \mathrm{ml}$. For Hytrast and Dionosil oily, both highly viscous suspensions, a maximum of $0.3 \mathrm{ml}$ could be instilled. Oblique lateral radiographs of the glands were made with occlusal dental film immediately after instillation and 5, 30 and (if necessary) 60 minutes later. The radiographs were used to evaluate the amount of glandular filling (Figs. 1 and 2) and evacuation of the contrast material. Seven days after the instilla- 
Table ॥

\begin{tabular}{|c|c|c|c|c|}
\hline $\begin{array}{l}\text { Contrast } \\
\text { medium }\end{array}$ & $\begin{array}{c}\text { Indications } \\
\text { (manufacturer) }\end{array}$ & $\begin{array}{l}\text { Application in } \\
\text { sialography by: }\end{array}$ & $\begin{array}{l}\text { Side-effects in } \\
\text { sialography }\end{array}$ & $\begin{array}{c}\text { Side effects in } \\
\text { other applications }\end{array}$ \\
\hline Conray 80 & $\begin{array}{l}\text { Angiography; cavography; } \\
\text { sialography; dacryocysto- } \\
\text { graphy; fistulography }\end{array}$ & (1) c $\mathrm{m}$ of choice; (2) & No & $\begin{array}{l}\text { (3) Sodium-containing c } \\
\mathrm{m} \text { (Conray } 80 \text { ) gener- } \\
\text { ally have smaller local } \\
\text { tolerance than meg- } \\
\text { lamine combinations }\end{array}$ \\
\hline Isopaque 440 & $\begin{array}{l}\text { Urography; angiography; } \\
\text { sialography }\end{array}$ & $(4) ;(5) ;(6) ;(7) ;(8)$ & $\begin{array}{l}\text { (6) Pain caused by paren- } \\
\text { chymatous filling; postsia- } \\
\text { lographic glandular swell- } \\
\text { ing during } 9 \text { hours caused } \\
\text { by the hypertonic } \mathrm{cm} \text {; } \\
\text { (7) rapid hydrolysis and } \\
\text { disappearance of } \mathrm{c} \mathrm{m} \text {. }\end{array}$ & $\begin{array}{l}(9 ; 10) \text { Small reversible } \\
\text { side effects in c m } \\
\text { study of kidncy }\end{array}$ \\
\hline Amipaque & $\begin{array}{l}\text { Various concentrations for } \\
\text { myelography; ventriculo- } \\
\text { graphy; angiography; } \\
\text { cavography }\end{array}$ & (6) & $\begin{array}{l}\text { (6) No pain or parenchyma- } \\
\text { tous filling; postsialograp- } \\
\text { hic glandular swelling for } \\
2 \text { hours }\end{array}$ & $\begin{array}{l}\text { Not very irritating in } \\
\text { myelography (11) and } \\
\text { arthrography (12) }\end{array}$ \\
\hline Urombrine 420 & Urography; sialography & No & No & No \\
\hline Urografin $76 \%$ & $\begin{array}{l}\text { Urography; angiography; } \\
\text { hysterosalpingography; } \\
\text { sialography }\end{array}$ & $\begin{array}{l}\text { (7);(13) c m of choice } \\
\text { (1);(14) }\end{array}$ & $\begin{array}{l}\text { (13) Normal postsialograp- } \\
\text { hic glandular function; } \\
\text { (15) some postsialographic } \\
\text { glandular inflammation } \\
\text { during some days; }(16) \text { no } \\
\text { postsialographic granulo- } \\
\text { matous reaction }\end{array}$ & $\begin{array}{l}(3 ; 9 ; 17) \text { Not very irri- } \\
\text { tating; (15) light in- } \\
\text { flammation after s c } \\
\text { application after } 1 \text { day } \\
\text { but not after } 7 \text { days }\end{array}$ \\
\hline Endografin & $\begin{array}{l}\text { Hysterosalpingography; ure- } \\
\text { thrography; fistulography; } \\
\text { sinusography; atresias; } \\
\text { galactography }\end{array}$ & $\begin{array}{l}\text { (18) c m of choice } \\
(1) ;(8) ;(19)\end{array}$ & $\begin{array}{l}\text { (16) No postsialographic } \\
\text { granulomatous reaction; } \\
\text { (19) reversible damage; } \\
\text { less subjective complaints } \\
\text { than with Urografin, Con- } \\
\text { ray } 80 \text { and Isopaque }\end{array}$ & $\begin{array}{l}\text { (17; } 20 ; 21) \text { Locally } \\
\text { (very) irritating; }(22) \\
\text { toxic after intravenous } \\
\text { instillation; (19) re- } \\
\text { versible damage after } \\
\text { s c application during } \\
7 \text { days }\end{array}$ \\
\hline Hytrast & $\begin{array}{l}\text { Bronchography; laryngogra- } \\
\text { phy; cystography; fistulo- } \\
\text { graphy }\end{array}$ & $(23) ;(24) ;(25)$ & $\begin{array}{l}\text { (23) Postsialographic } \mathrm{cm} \\
\text { retention for 3-4 days; } \\
\text { (24) no histologic changes } \\
\text { of glands after } \mathrm{c} \mathrm{m} \text { reten- } \\
\text { tion; (25) long-standing } \\
\text { glandular swelling after c } \\
\text { m retention }\end{array}$ & $\begin{array}{l}\text { (11; } 26 \text { to } 31) \text { Postbron- } \\
\text { chographic } \mathrm{c} \text { m reten- } \\
\text { tion with inflamma- } \\
\text { tion and fibrosis; }(26) \\
\mathrm{c} \text { m retention longer } \\
\text { than } 10 \text { days and ex- } \\
\text { tensive inflammation } \\
\text { and fibrosis after s c } \\
\text { application }\end{array}$ \\
\hline
\end{tabular}

$\mathrm{C} \mathrm{m}=$ Contrast medium.

$\mathrm{S} \mathrm{c}=$ Subcutaneous.

tion, the glands were removed with the aid of general anesthesia and radiographed to determine contrast medium retention and processed for histologic evaluation with hematoxylin and eosin staining.

The effects of instillation of contrast media into the subcutaneous soft tissues, a situation comparable to unintentional extravasation in sialography, were studied in rats. Following disinfection of the skin surface, $0.2 \mathrm{ml}$ of each contrast material was injected into the subcutaneous tissue of each rat. Tissues were removed 2,8, and 70 days later and studied clinically, radiographically for contrast medium retention, and histologically (hematoxylin and eosin staining). Each material was tested three times.

\section{RESULTS \\ In vitro experiments}

Iodine salt concentration. The determination of the iodine salt content for each of the contrast media investigated are given in Table I. Differences from the stated values exceeding 5\% were found for Amipaque (-7.7\%), Urografin $76 \% \quad(-6.5 \%)$, Hytrast $(-6 \%)$, and Dionosil oily $(+12.4 \%)$.

Dilution effects. Dilution effects were determined 
TABLE (cont'd)

\begin{tabular}{|c|c|c|c|c|}
\hline $\begin{array}{l}\text { Contrast } \\
\text { medium }\end{array}$ & $\begin{array}{c}\text { Indications } \\
\text { (manufacturer) }\end{array}$ & $\begin{array}{l}\text { Application in } \\
\text { sialography by: }\end{array}$ & $\begin{array}{l}\text { Side effects in } \\
\text { sialography }\end{array}$ & $\begin{array}{l}\text { Side effects in } \\
\text { other applications }\end{array}$ \\
\hline Dionosil oily & Bronchongraphy & $(32) ;(33)$ & $\begin{array}{l}\text { (15) c m retention with in- } \\
\text { flammation and parenchy- } \\
\text { mal degeneration } 7 \text { days } \\
\text { after sialography; (16) } \\
\text { postsialographic granulo- } \\
\text { matous reaction; }(34) \text { the } \\
\text { arachis oil in the } \mathrm{c} \mathrm{m} \\
\text { causes inflammation, fi- } \\
\text { brosis granulomas, and ne- } \\
\text { crosis of stroma, and vac- } \\
\text { uolation of parcnchyma } \\
\text { and stroma } 3.5 \text { weeks af- } \\
\text { ter sialography }\end{array}$ & $\begin{array}{l}(11 ; 17 ; 26 ; 29 ; 35) \\
\text { Postbronchographic c } \\
\text { m retention and } \\
\text { chronic inflammation; } \\
(15 ; 26 ; 36) \text { long- } \\
\text { standing relention and } \\
\text { moderate-grave in- } \\
\text { flammation after s c } \\
\text { application }\end{array}$ \\
\hline Lipiodol UF & $\begin{array}{c}\text { Cholangiography; hyster- } \\
\text { osalpingography; lym- } \\
\text { phography; sialography }\end{array}$ & $\begin{array}{l}(11) ;(14) \text { C m of choice } \\
(1) ;(5) ;(7) ;(13) ;(33) \\
(37)\end{array}$ & $\begin{array}{l}(7 ; 16 ; 38 ; 39) \text { No postsialo- } \\
\text { graphic damage after peri- } \\
\text { ods between I and } 300 \\
\text { days; (15) light postsialo- } \\
\text { graphic inflammation dur- } \\
\text { ing some days; (37) chron- } \\
\text { ic inflammation after c m } \\
\text { extravasation from paren- } \\
\text { chyma }\end{array}$ & $\begin{array}{l}\text { (15) } \mathrm{C} m \text { retention and } \\
\text { inflammation for over } \\
14 \text { days after s c ap- } \\
\text { plication; } \mathrm{c} m \text { reten- } \\
\text { tion results in chronic } \\
\text { irritation in bronchog- } \\
\text { raphy }(40 ; 41) \text {; myelo- } \\
\text { graphy }(42 ; 43) \text {, and } \\
\text { lymphography (11; } \\
41)\end{array}$ \\
\hline Myodil & $\begin{array}{l}\text { Myelography; ventricu- } \\
\text { lography }\end{array}$ & $\begin{array}{l}(5 ; 32 ; 44) \mathrm{Cm} \text { of } \\
\text { choice; }(1) ;(7) ;(8) ;(33 \\
(45)\end{array}$ & $\begin{array}{l}\text { (8) Postsialographic granulo- } \\
\text { mata possible; }(14 ; 45) \\
\text { granulomata after c m ex- } \\
\text { travasation from paren- } \\
\text { chyma; (16) no postsialo- } \\
\text { graphic granuloma }\end{array}$ & $\begin{array}{l}(11 ; 17 ; 42 ; 43) \text { Chronic } \\
\text { inflammation possible } \\
\text { after c m retention; } \\
\text { (42) long-standing re- } \\
\text { tention after s c appli- } \\
\text { cation }\end{array}$ \\
\hline Duroliopaque & $\begin{array}{l}\text { Myelography; ventricu- } \\
\text { lography }\end{array}$ & No & No & $\begin{array}{l}\text { (42) Chronic irritation } \\
\text { after myelography; } \\
\text { long-standing reten- } \\
\text { tion without irritation } \\
\text { after s c application }\end{array}$ \\
\hline
\end{tabular}

densitometrically and a decrease of less than $10 \%$ from the original iodine salt concentration was classified as small; 10 to $20 \%$ as moderate; 20 to $30 \%$ as high; and over $30 \%$ as very high. Typical radiographs of the horizontal portion of the tube at $t_{1}, t_{2}$, and $t_{3}$ for Urombrine $\mathbf{4 2 0}$ and Hytrast are shown in Figs. 3 and 4. Graphs of the iodine salt concentration at different sites for the time intervals and contrast media mentioned are shown in Figs. 5 and 6 . In these figures a progressive dilution of Urombrine 420 along the length of the tube and with time can be seen. The iodine salt concentration after initial and prolonged dilution of the media is presented graphically in Fig. 7. The oily media showed no dilution, and this resulted in moderate to very high iodine salt concentrations at $t_{1}, t_{2}$, and $t_{3}$.

The initial dilution $\left(t_{1}\right)$ of the other media was moderate to high for Isopaque 440, Urombrine 420 , and Urografin 76\%; high for Conray 80 and Hytrast; high to very high for Amipaque and Endografin. The highest iodine salt concentrations with these media were found for Conray 80, Isopaque 440, Hytrast, and Urombrine 420. Both Amipaque and Endografin demonstrated low to very low iodine salt concentrations in spite of their relatively high viscosity and low osmolality.

Prolonged dilution of water-soluble media halfway along the tube at $t_{2}$ ( 1 minute) was determined densitometrically, and a decrease smaller than $10 \%$ relative to the iodine salt concentration at $t_{1}$ was classified as small; 10 to $20 \%$ as moderate; 20 to $30 \%$ as high; and over $30 \%$ as very high. Prolonged dilution at $\mathrm{t}_{2}$ was small for Isopaque 440 , Amipaque, and Hytrast; moderate for Urombrine 420 and Endografin; high for Conray 80; and very high for Urografin $76 \%$. 


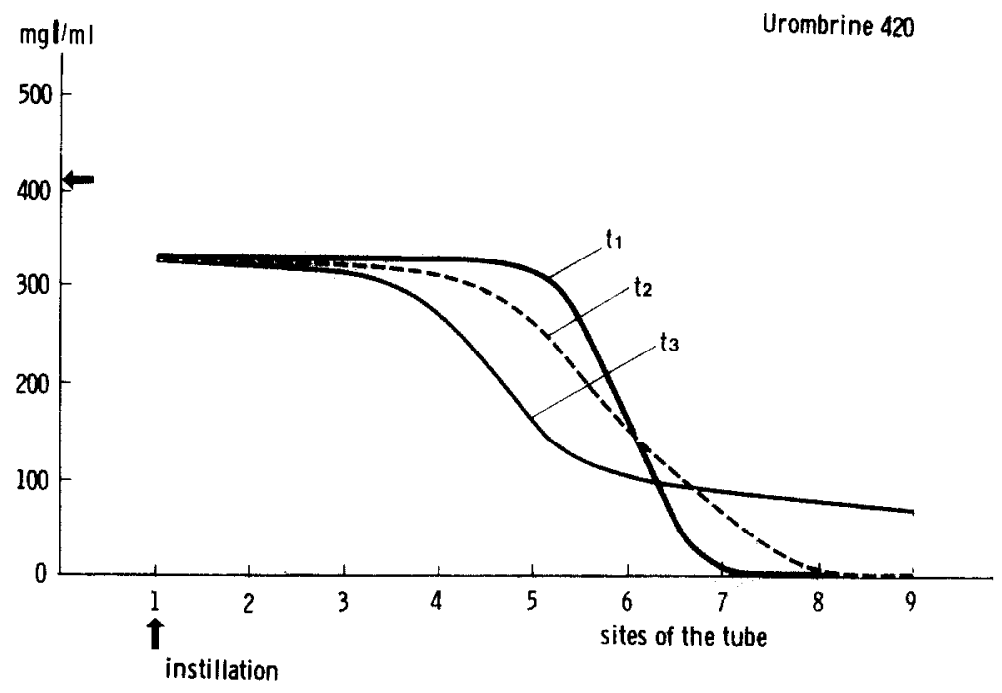

Flg. 5. Graphic presentation of the iodine salt concentration $(\mathrm{mgl} / \mathrm{ml})$ at different sites of the polyethylene tubes from Fig. 3 for the time intervals mentioned. Contrast medium: Urombrine 420.

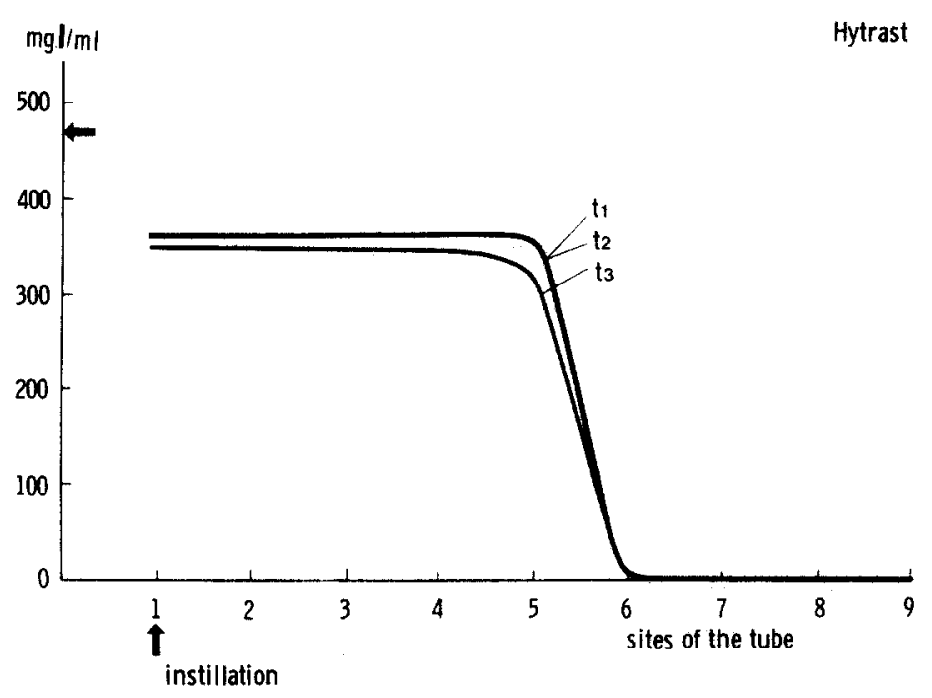

Fig. 6. Graphic presentation of the iodine salt concentration $(\mathrm{mgl} / \mathrm{ml})$ at different sites of the polyethylene tubes from Fig. 4 for the time intervals mentioned. Contrast medium: Hytrast.

Prolonged dilution halfway along the tube at $t_{3}(5$ minutes) was small for Hytrast; moderate for Amipaque; high for Conray 80 , Isopaque 440, and Endografin; and very high for Urombrine 420 and Urografin $76 \%$.

The absolute iodine salt concentration of the water soluble media at $t_{2}$ and $t_{3}$ was most favorable for Hytrast (moderate) and for Conray 80 and Isopaque 440 (low). Dilution of the other water-soluble media resulted in very low iodine salt concentrations. The most favorable results in the dilution experiments were successively found for Lipiodol UF, Dionosil oily, Myodil, Duroliopaque, Hytrast, Conray 80 , and Isopaque 440.

Evacuation of contrast media. Typical radiographs of the narrow lumen in tubes filled with Isopaque 440 and Lipiodol UF in the evacuation study are shown in Figs. 8 and 9. The results of the evacuation study for all media are given in Table III. Most of the water-soluble media show an almost complete evacuation in 5 minutes. Amipaque and Hytrast were evacuated much slower, probably as a 

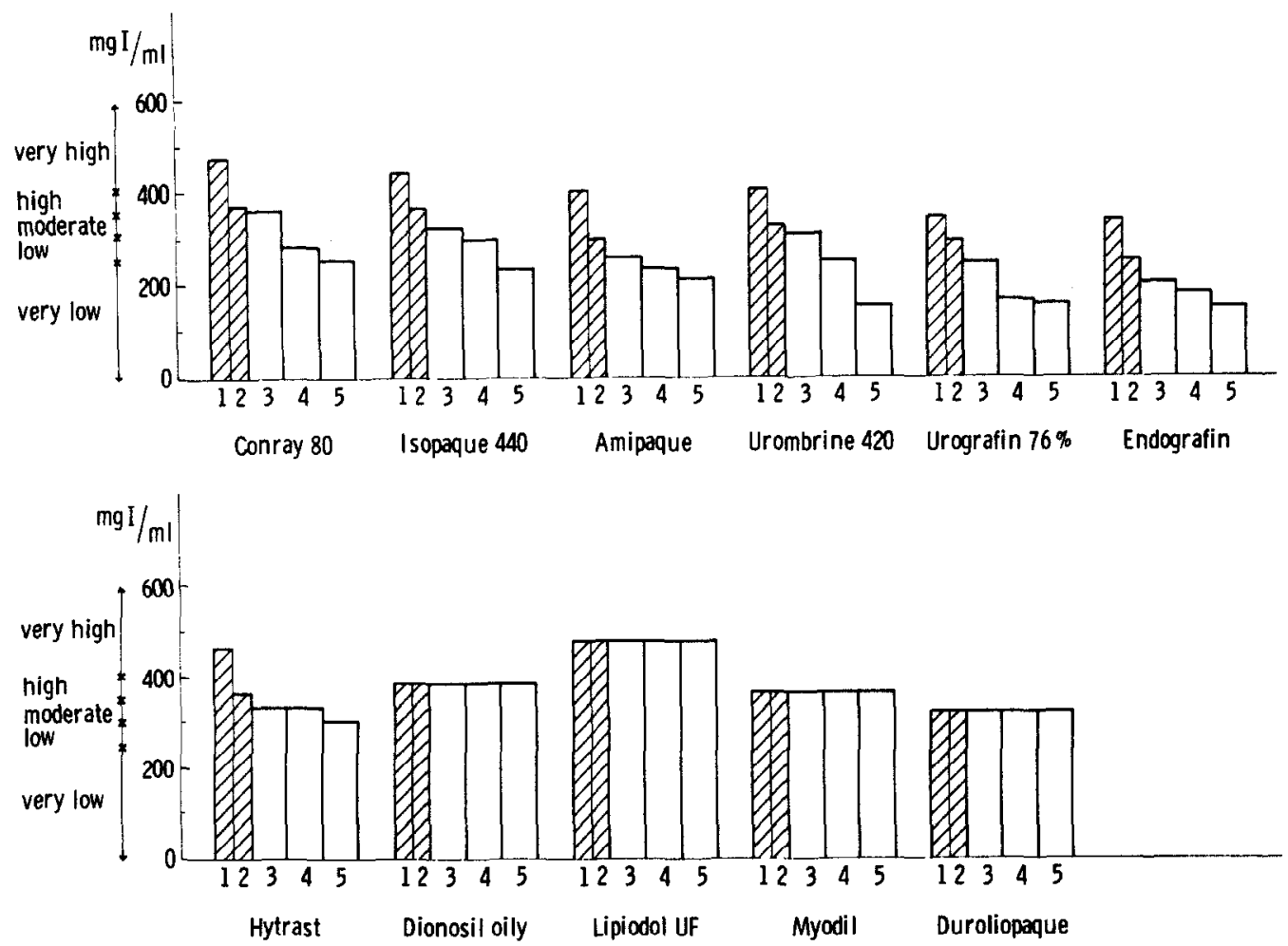

Fig. 7. Iodine salt concentration $(\mathrm{mgI} / \mathrm{ml})$ after initial $\left(t_{1}\right)$ and prolonged $\left(t_{2}\right.$ and $\left.t_{3}\right)$ dilution of the contrast media. $1=$ Undiluted contrast medium; $2=$ at instillation place at $t_{1}(=0 \mathrm{~min}) ; 3=$ halfway along the tube at $t_{1}(=0 \mathrm{~min}) ; 4=$ halfway along the tube at $t_{2}(=1 \mathrm{~min}) ; 5=$ halfway along the tube at $t_{3}$ (= $5 \mathrm{~min}$ ). An iodine salt concentration smaller than $250 \mathrm{mg} / \mathrm{ml}$ was classified as very low; 250 to 300 $\mathrm{mg} / \mathrm{ml}$, low; 300 to $350 \mathrm{mg} / \mathrm{ml}$, moderate; 350 to $400 \mathrm{mg} / \mathrm{ml}$, high; over $400 \mathrm{mg} / \mathrm{ml}$, very high.

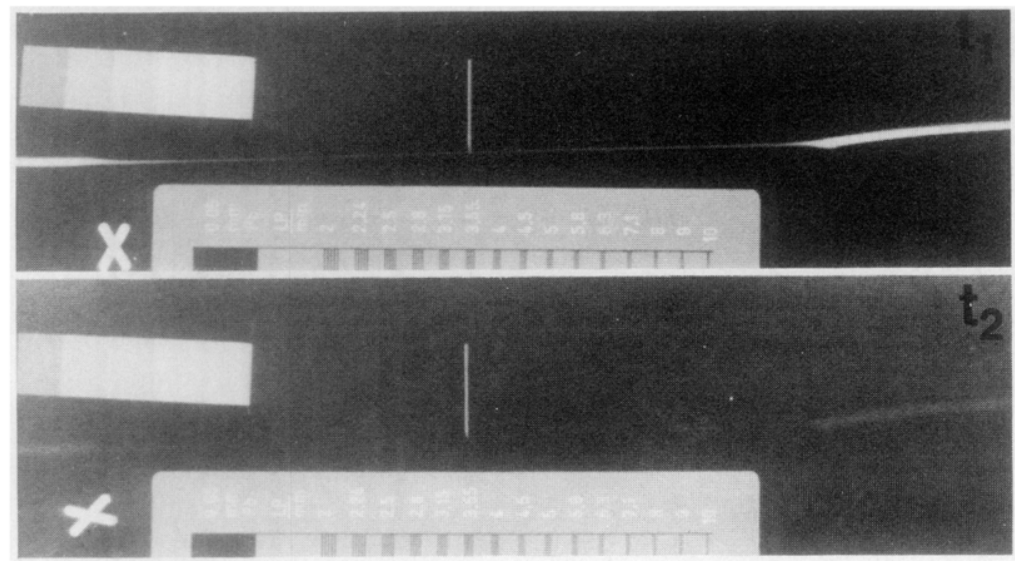

Fig. 8. Radiographs used for the study of contrast medium evacuation from a polyethylene tube with a localized narrowing at $t_{1}(=0 \mathrm{~min})$ and $t_{2}(=5 \mathrm{~min})$. Contrast medium: Isopaque 440 . At $t_{2}$ the evacuation is almost complete. 


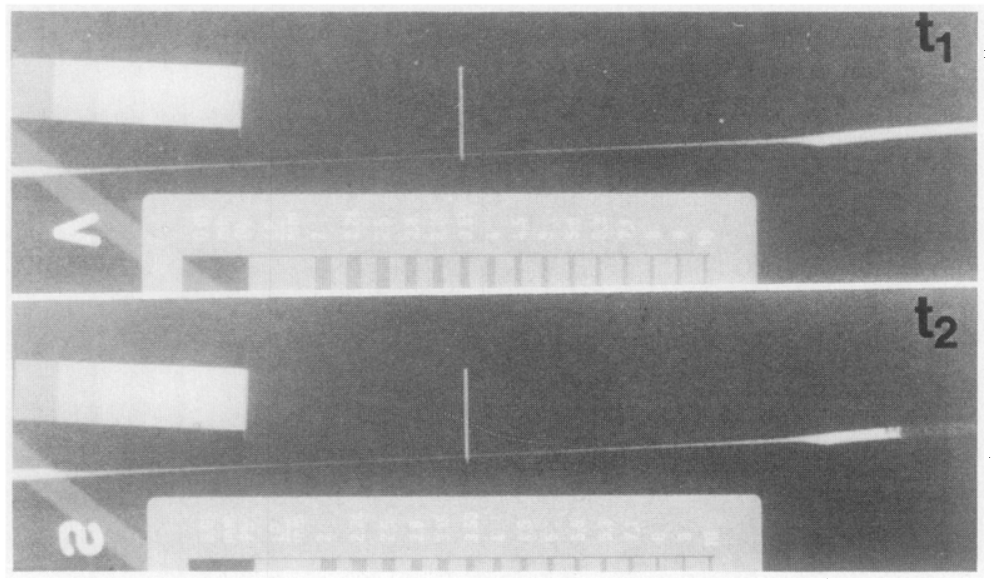

Fig.9. See legend for Fig. 8. Contrast medium: Lipiodol UF. At $t_{2}$ the contrast medium has moved slightly toward the instillation point (left) as a result of the hydrostatic pressure (right): incomplete evacuation.

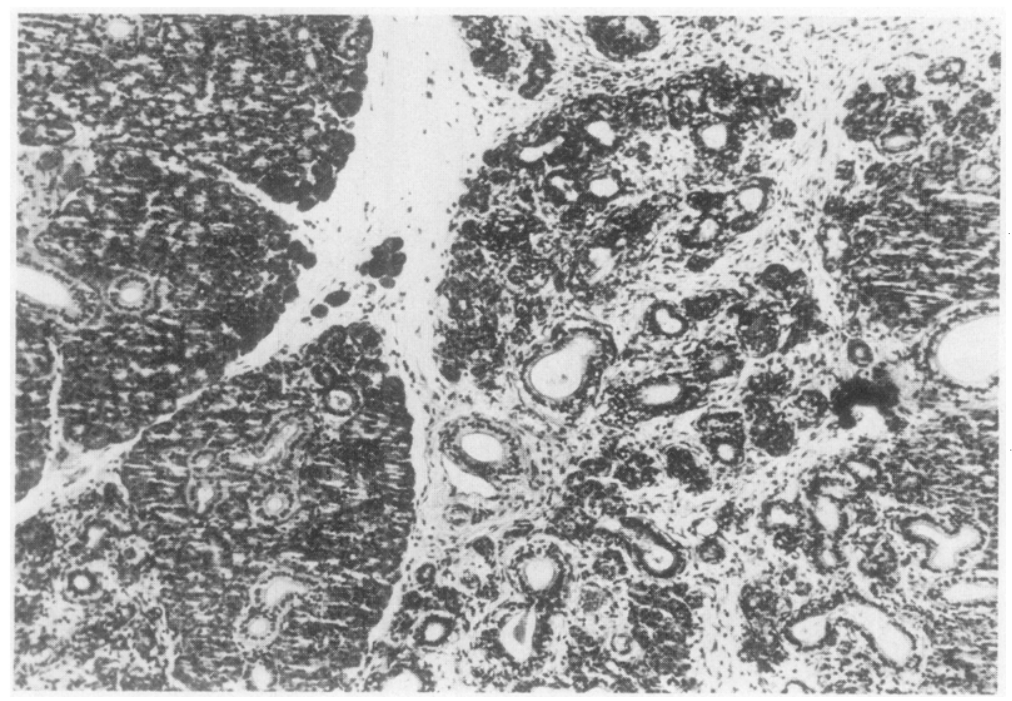

Fig. 10. Photomicrograph of rabbit submandibular gland removed 7 days after sialography with $0.4 \mathrm{ml}$ Endografin (overfilling). Some fibrosis of the parenchyma, hyperemia, and extensive invasion with lymphocytes and macrophages are visible. (Hematoxylin and eosin stain. Magnification, $\times 40$.)

result of their higher viscosity. The same is true for the oily media except for Duroliopaque, which was almost completely evacuated in 5 minutes.

The low-viscosity water-soluble media and Duroliopaque seem more suited for the study of salivary gland function than the more viscous media.

\section{In vivo experiments}

Evacuation of contrast media. Results of the evacuation of contrast media after sialography in rabbits are given in Table IV. Radiographs made 30 minutes after sialography showed complete evacuation in both normally filled and overfilled glands for most of the water-soluble media. The suspensions and the oily media had longer retention times, and in the case of overfilled glands retention was found for most of these media after 7 days.

Tissue reaction after normal glandular filling. Results of the histologic evaluation of the submandibular glands removed 7 days after sialography are presented in Table V. Histologic changes occurred following normal glandular filling with six of the tested contrast media. No abnormalities were seen after sialography with Amipaque, Urografin 76\%, Lipiodol UF, Myodil, and Duroliopaque. Some ductectasia was visible with Conray 80. Postsialographic 


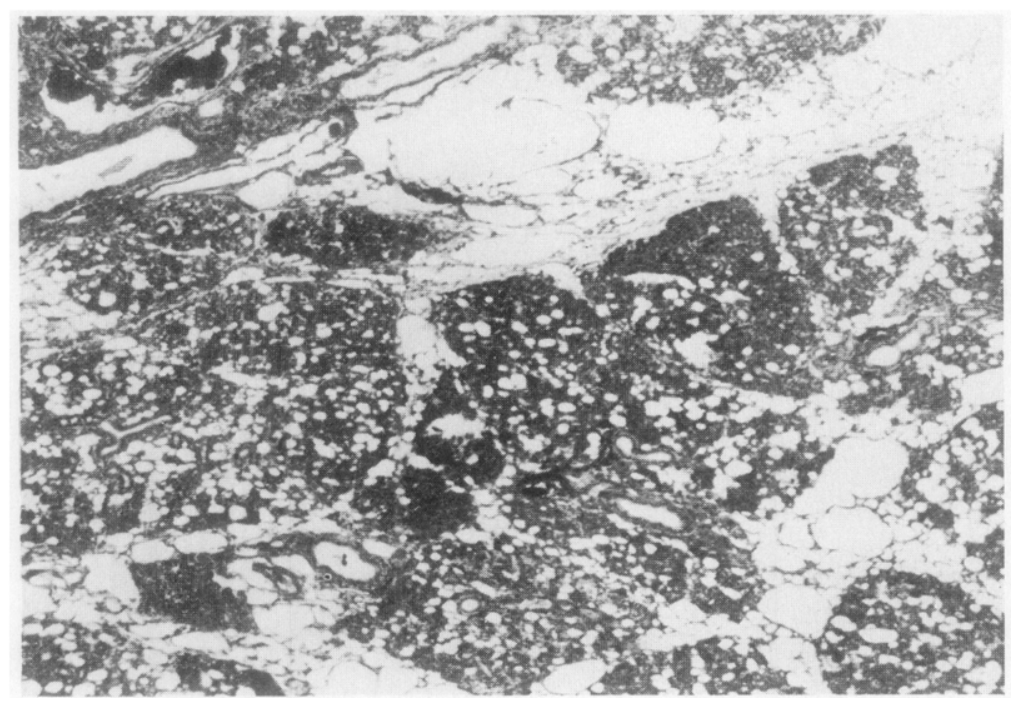

Fig. 11. Photomicrograph of rabbit submandibular gland removed 7 days after sialography with $0.4 \mathrm{ml}$ Lipiodol UF (overfilling). Note destruction of the parenchyma, resulting in contrast-medium vacuoles surrounded by macrophages. (Hematoxylin and eosin stain. Magnification, $\times 15$.)

Table III Evacuation of the contrast media after 5 minutes $\left(\mathrm{t}_{\mathrm{g}}\right)^{*}$

\begin{tabular}{l|c|c|c}
\hline \multicolumn{1}{c|}{$\begin{array}{c}\text { Contrast } \\
\text { medium }\end{array}$} & Over 95\% & 5-10\% & Less than 5\% \\
\hline Conray 80 & $\mathrm{x}$ & & \\
Isopaque 440 & $\mathrm{x}$ & $\mathrm{x}$ & \\
Amipaque & & & \\
Urombrine 420 & $\mathrm{x}$ & & \\
Urografin 76\% & $\mathrm{x}$ & & $\mathrm{x}$ \\
Endografin & $\mathrm{x}$ & & $\mathrm{x}$ \\
Hytrast & & & $\mathrm{x}$ \\
Dionosil oily & & & \\
Lipiodol UF & & $\mathrm{x}$ & \\
Myodil & & & \\
Duroliopaque & $\mathrm{x}$ & \\
\hline
\end{tabular}

*Decrease in the iodine salt concentration at $t_{2}$ relative to $t_{1}$ in precent

glandular fibrosis and/or the presence of inflammatory cells occurred with the other media; in order of increasingly severe tissue reactions, these media are Dionosil oily, Urombrine 420, Isopaque 440, Endografin, and Hytrast. In addition to these changes, some glandular necrosis was found after the instillation of Hytrast. Some of the observed stromal abnormalities probably resulted from the extravasation of contrast media into the stroma. ${ }^{48}$

Tissue reaction after glandular overfilling. Glandular overfilling resulted in histologic changes with all media. Some glandular fibrosis and/or the presence of inflammatory cells occurred with Amipaque,
Table IV

\begin{tabular}{|c|c|c|c|c|c|}
\hline $\begin{array}{l}\text { Contrast } \\
\text { medium }\end{array}$ & $\begin{array}{c}\text { Volume } \\
(\mathrm{ml})\end{array}$ & $5 \mathrm{~min}$ & $30 \mathrm{~min}$ & $60 \mathrm{~min}$ & I week \\
\hline \multirow[t]{2}{*}{ Conray 80} & 0.2 & + & - & - & - \\
\hline & 0.4 & + & - & - & - \\
\hline \multirow[t]{2}{*}{ Isopaque 440} & 0.2 & + & - & - & - \\
\hline & 0.4 & + & - & - & - \\
\hline \multirow[t]{2}{*}{ Amipaque } & 0.2 & + & - & - & - \\
\hline & 0.4 & + & \pm & - & - \\
\hline \multirow[t]{2}{*}{ Urombrine 420} & 0.2 & + & - & - & - \\
\hline & 0.4 & + & - & - & - \\
\hline \multirow[t]{2}{*}{ Urografin $76 \%$} & 0.2 & + & - & - & - \\
\hline & 0.4 & + & - & - & - \\
\hline \multirow[t]{2}{*}{ Endografin } & 0.2 & + & - & - & - \\
\hline & 0.4 & + & \pm & - & - \\
\hline \multirow[t]{2}{*}{ Hytrast } & 0.2 & + & + & + & - \\
\hline & $0.3^{*}$ & + & + & + & + \\
\hline \multirow[t]{2}{*}{ Dionosil oily } & 0.2 & + & + & \pm & - \\
\hline & $0.3^{*}$ & + & + & + & - \\
\hline \multirow[t]{2}{*}{ Lipiodol UF } & 0.2 & + & + & - & - \\
\hline & 0.4 & + & + & + & + \\
\hline \multirow[t]{2}{*}{ Myodil } & 0.2 & + & + & - & - \\
\hline & 0.4 & + & + & + & + \\
\hline \multirow[t]{2}{*}{ Duroliopaque } & 0.2 & + & + & - & - \\
\hline & 0.4 & + & + & + & + \\
\hline
\end{tabular}

- = Complete elimination; $\pm=$ slight retention; $+=$ retention.

*A maximum of $0.3 \mathrm{ml}$ of this (viscous) medium could be injected

Isopaque 440 , Urografin $76 \%$, and Conray 80 . These changes were more pronounced, and sometimes accompanied by localized necrosis, with Endografin (Fig. 10), Urombrine 420, Dionosil oily, and Hytrast. Extensive destruction of the parenchyma 


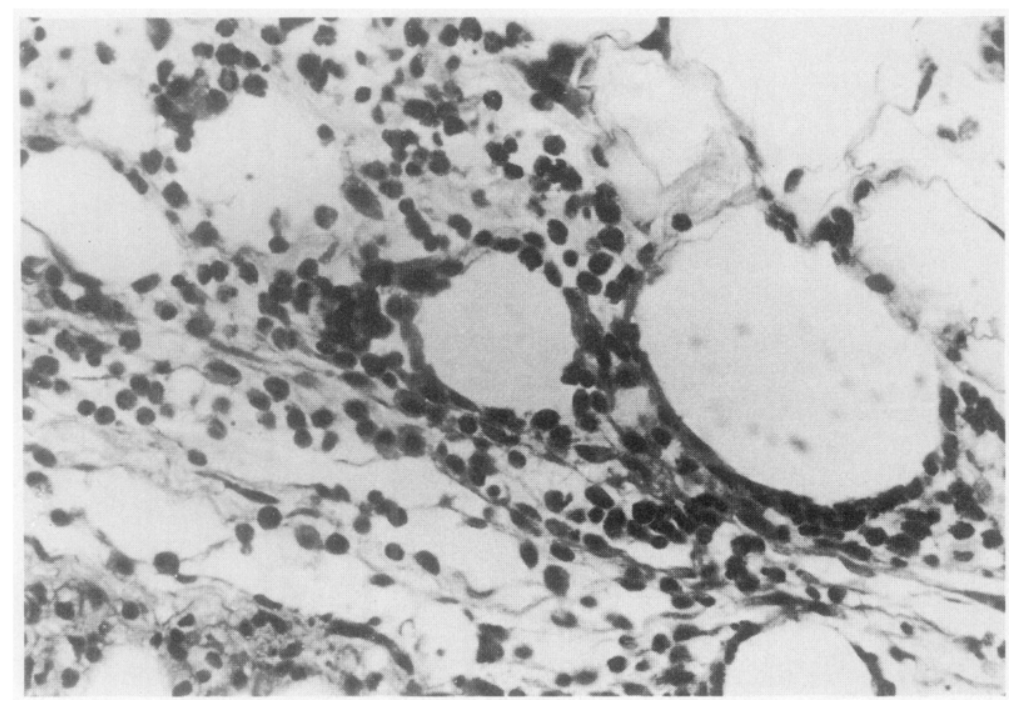

Fig. 12. Photomicrograph of rabbit submandibular gland removed 7 days after sialography with $0.4 \mathrm{ml}$ Duroliopaque (overfilling). Extensive vacuolation and destruction of the parenchyma and infiltration with neutrophils are visible. (Hematoxylin and eosin stain. Magnification, $\times 150$.)

Table V

\begin{tabular}{|c|c|c|}
\hline Contrast medium & Normal filling $(0.2 \mathrm{ml})$ & Overfilling $(0.4 \mathrm{ml})$ \\
\hline Physiologic saline & Normal & Normal \\
\hline Conray 80 & Some ductectasia & $\begin{array}{l}\text { Some fibrosis of parenchyma and invasion with } \\
\text { lymphocytes, plasma cells, and macrophages; } \\
\text { also fibrosis of stroma }\end{array}$ \\
\hline Isopaque 440 & $\begin{array}{l}\text { Some fibrosis of parenchyma and invasion with a } \\
\text { few lymphocytes }\end{array}$ & Same as with $0.2 \mathrm{ml}$ \\
\hline Amipaque & Normal & Stromal invasion with a few neutrophils \\
\hline Urombrine 420 & Some fibrosis of stroma & $\begin{array}{l}\text { Moderate to grave fibrosis of parenchyma and } \\
\text { invasion with some lymphocytes and neutrophils }\end{array}$ \\
\hline Urografin $76 \%$ & Normal & $\begin{array}{l}\text { Localized fibrosis at glandular periphery and some } \\
\text { invasion with neutrophils }\end{array}$ \\
\hline Endografin & $\begin{array}{l}\text { Some fibrosis of parenchyma, hyperemia, and } \\
\text { invasion with lymphocytes and neutrophils }\end{array}$ & $\begin{array}{l}\text { Some fibrosis of parenchyma, more hyperemia, } \\
\text { and extensive invasion with lymphocytes and } \\
\text { macrophages (Fig. 10) }\end{array}$ \\
\hline Hytrast* & $\begin{array}{l}\text { Fibrosis of parenchyma and invasion with } \\
\text { lymphocytes and neutrophils; some stromal } \\
\text { necrosis, extending into parenchyma and } \\
\text { moderate invasion with macrophages }\end{array}$ & Same as with $0.2 \mathrm{ml}$ \\
\hline Dionosil oily* & $\begin{array}{l}\text { Hyperemia and some invasion of stroma with } \\
\text { macrophages and neutrophils }\end{array}$ & $\begin{array}{l}\text { Same as with } 0.2 \mathrm{ml} \text { and, in addition, localized } \\
\text { necrosis within the stroma }\end{array}$ \\
\hline Lipiodol UF & Normal & $\begin{array}{l}\text { Parenchymal destruction resulting in } \mathrm{cm} \text { vacuoles } \\
\text { surrounded by macrophages (Fig. (1) }\end{array}$ \\
\hline Myodil & Normal & $\begin{array}{l}\text { Extensive parenchymal vacuolation and invasion } \\
\text { with lymphocytes and some neutrophils }\end{array}$ \\
\hline Duroliopaque & Normal & $\begin{array}{l}\text { Extensive parenchymal vacuolation and extensive } \\
\text { invasion with neutrophils (Fig. 12) }\end{array}$ \\
\hline
\end{tabular}

*A maximum of $0.3 \mathrm{ml}$ of this viscous medium could be instilled into the salivary gland.

and the formation of contrast medium vacuoles were found after glandular overfilling with Lipiodol UF (Fig. 11), Myodil, and Duroliopaque (Fig. 12).

Subcutaneous reactions. Results for the subcuta- neous injection of contrast medium in rats are given in Table VI. Radiographically visible contrast medium retention was found in varying degrees with the suspensions and all oily media in the 2 - and 8-day 


\begin{tabular}{|c|c|c|c|c|c|c|c|c|c|}
\hline \multirow{2}{*}{$\begin{array}{l}\text { Contrast } \\
\text { medium }\end{array}$} & \multicolumn{3}{|c|}{$\begin{array}{c}\text { Clinical } \\
\text { induration (days) }\end{array}$} & \multicolumn{3}{|c|}{$\begin{array}{c}\text { Radiographic } \\
\text { c } m \text { retention (days) }\end{array}$} & \multicolumn{3}{|c|}{ Histological inflammation and/or $c m$ retention (days) } \\
\hline & 2 & 8 & 70 & 2 & 8 & 70 & 2 & 8 & 70 \\
\hline $\begin{array}{l}\text { Physiologic } \\
\text { saline }\end{array}$ & - & - & - & - & - & - & - & - & - \\
\hline Conray 80 & \pm & - & - & - & - & - & $\begin{array}{l}\text { +; Lymphocytes, } \\
\text { macrophages and } \\
\text { neutrophils; some } \\
\text { necrosis of } \\
\text { musculature }\end{array}$ & $\begin{array}{l}+ \text {; Some fibrosis; some } \\
\text { lymphocytes and } \\
\text { macrophages }\end{array}$ & - \\
\hline $\begin{array}{l}\text { Isopaque } \\
440\end{array}$ & \pm & \pm & - & - & - & - & +; Some lymphocytes & $\begin{array}{c}+/++; C \mathrm{~m} \text { vacuoles } \\
\text { and lymphocytes }\end{array}$ & - \\
\hline Amipaque & - & - & - & - & - & - & - & - & - \\
\hline $\begin{array}{l}\text { Urombrine } \\
420\end{array}$ & - & - & - & - & - & - & +; Some lymphocytes & $\begin{array}{c}++; C \text { m vacuoles; } \\
\text { moderate infiltrate } \\
\text { of macrophages }\end{array}$ & - \\
\hline $\begin{array}{l}\text { Urografin } \\
76 \%\end{array}$ & - & \pm & - & - & - & - & - & $\begin{array}{l}++; \mathrm{C} \mathrm{m} \text { vacuoles; } \\
\text { moderate infiltrate } \\
\text { of macrophages } \\
\text { (Fig. 13) }\end{array}$ & - \\
\hline Endografin & \pm & \pm & - & - & - & - & $\begin{array}{l}++/+ \text {; Moderate } \\
\text { infiltrate of } \\
\text { neutrophils }\end{array}$ & $\begin{array}{l}+ \text {; Some lymphocytes } \\
\text { some necrosis of } \\
\text { musculature }\end{array}$ & - \\
\hline Hytrast & ++ & & ++ & ++ & ++ & ++ & $\begin{array}{l}++++; \text { Retained } \mathrm{c} \mathrm{m} \\
\text { granulation tissue; } \\
\text { many macrophages } \\
\text { and neutrophils }\end{array}$ & $\begin{array}{c}+++; \text { Slightly decreased } \\
\text { reaction; lymphocytes, } \\
\text { neutrophils, } \\
\text { macrophages, fibrosis }\end{array}$ & $\begin{array}{l}\text { +; Retained c m with } \\
\text { connective tissue } \\
\text { capsule; some } \\
\text { lymphocytes and } \\
\text { macrophages (Fig. } \\
\text { 15) }\end{array}$ \\
\hline Dionosil oily & \pm & - & - & + & + & - & $\begin{array}{l}++; \text { Retained } \mathrm{c} \mathrm{m} \text {; } \\
\text { neutrophils }\end{array}$ & $\begin{array}{l}++; C \mathrm{~m} \text { vacuoles } \\
\text { with moderate } \\
\text { infiltrate of } \\
\text { lymphocytes and } \\
\text { macrophages (Fig. } \\
\text { 14) }\end{array}$ & - \\
\hline Lipiodol UF & - & \pm & - & ++ & $+t$ & - & - & $\begin{array}{c}+; \text { C m vacuoles with } \\
\text { some lymphocytes } \\
\text { and macrophages }\end{array}$ & - \\
\hline Myodil & - & \pm & - & ++ & ++ & - & $\begin{array}{l}+\mathrm{C} m \text { vacuoles with } \\
\text { lymphocytes and } \\
\text { macrophages }\end{array}$ & $\begin{array}{l}++ \text {; Same reaction, } \\
\text { somewhat more } \\
\text { pronounced }\end{array}$ & - \\
\hline $\begin{array}{l}\text { Duroli- } \\
\text { opaque }\end{array}$ & - & - & - & + & + & + & $\begin{array}{c}+ \text {; Some lymphocytes } \\
\text { and macrophages }\end{array}$ & $+; \mathrm{c} \mathrm{m}$ vacuoles & $\begin{array}{c}+; C \text { m vacuoles } \\
\text { surrounded by } \\
\text { macrophages }\end{array}$ \\
\hline
\end{tabular}

$-=$ No abnormalities present.

$\pm /+/++/+++/++++=$ Abnormalities found in various degrees.

skin tissue specimens. Radiographs of the 70-day specimens only showed retained Hytrast and Duroliopaque.

Clinical and/or histologic abnormalities were found in specimens at 2 and 8 days for all media except Amipaque. All specimens that showed clinical induration also demonstrated histologically visible changes. In order of increasing harmfulness after subcutaneous injection, these media are Conray 80 , Lipiodol UF, Endografin, Isopaque 440, Durolio- paque, Urografin $76 \%$ (Fig. 13), Urombrine 420 , Myodil, Dionosil oily (Fig. 14), and Hytrast. The 70-day skin tissue specimens only showed abnormalities for Hytrast (Fig. 15) and Duroliopaque.

\section{DISCUSSION AND CONCLUSIONS}

The properties of the tested contrast media are summarized in Table VII. Of the water-soluble media evaluated, Conray 80 seems to be the most suited for use in sialography. Amipaque, with its low 


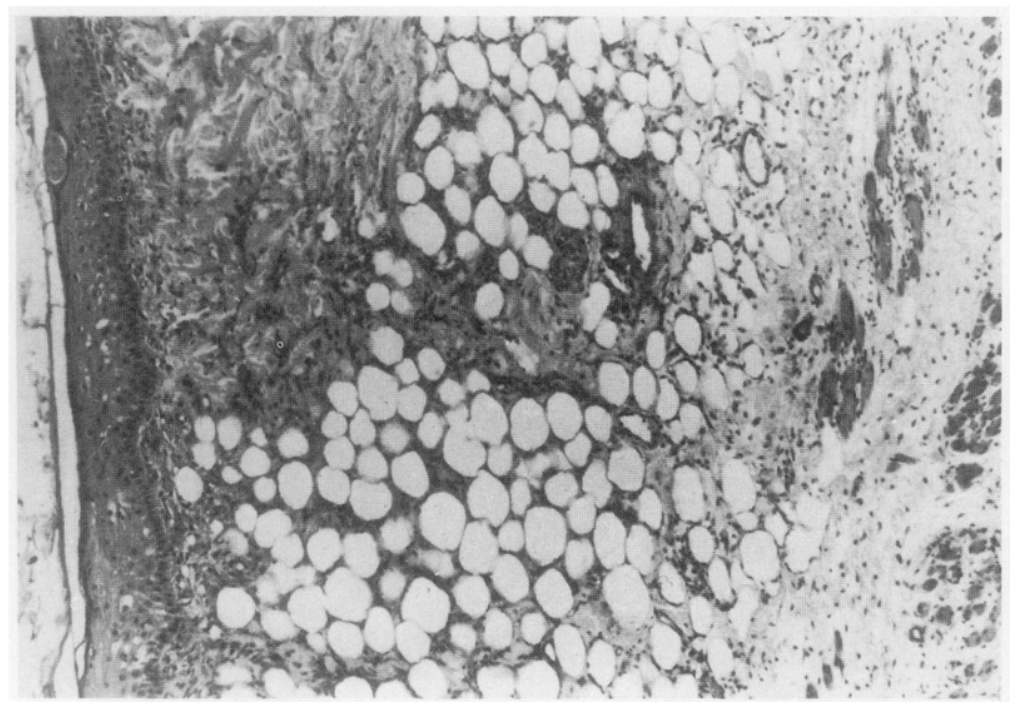

Fig. 13. Photomicrograph of rat skin tissue removed 8 days after subcutaneous injection of $0.2 \mathrm{ml}$ Urografin $76 \%$. Contrast-medium vacuoles and a moderately dense infiltrate of macrophages are visible in the subcutaneous tissue. (Hematoxylin and eosin stain. Magnification, $\times 15$.)

Table VII

\begin{tabular}{|c|c|c|c|c|c|c|c|c|}
\hline \multirow[b]{2}{*}{ Contrast medium } & \multicolumn{2}{|c|}{$\begin{array}{c}\text { Iodine salt } \\
\text { concentration after } \\
\text { initial }(a) \text { and } \\
\text { prolonged }(b) \text { dilution }\end{array}$} & \multicolumn{3}{|c|}{$\begin{array}{l}C m \text { evacuation in vitro }(a) \\
\text { and in vivo after normal } \\
\text { filling }(b) \text { overfilling }(c)\end{array}$} & \multicolumn{2}{|c|}{$\begin{array}{c}\text { Effect on salivary gland } \\
\text { tissue after normal filling } \\
\text { (a) and overfilling }(b)\end{array}$} & \multirow{2}{*}{$\begin{array}{c}\text { Effect on } \\
\text { subcutaneous: } t \text { issues }\end{array}$} \\
\hline & $a$ & $b$ & $a$ & $b$ & $c$ & $a$ & $b$ & \\
\hline Conray 80 & + & - & ++ & + & + & \pm & - & - \\
\hline Isopaque 440 & \pm & - & ++ & + & + & - & - & - to -- \\
\hline Amipaque & - & -- & - & + & \pm & + & - & + \\
\hline Urombrine 420 & \pm & -- & ++ & + & + & - & -- & - to -- \\
\hline Urografin $76 \%$ & - & -- & ++ & + & + & + & - & - to -- \\
\hline Endografin & -- & -- & $+t$ & + & \pm & - & -- & -- to - \\
\hline Hytrast & \pm & \pm & -- & - & -- & -- & -- & --- \\
\hline Dionosil oily & + & + & -- & - & - & - & -- & -- \\
\hline Lipiodol UF & ++ & ++ & -- & \pm & -- & + & --- & - \\
\hline Myodil & + & + & - & \pm & -- & + & --- & - to -- \\
\hline Duroliopaque & \pm & \pm & ++ & \pm & -- & + & $-\cdots$ & -- \\
\hline
\end{tabular}

Plus values $=$ Favorable properties.

Minus values $=$ Unfavorable properties.

osmolality and relatively high viscosity, is much less radiopaque after dilution. Isopaque 440 is more noxious than the two water-soluble media previously mentioned. Of the oily media investigated, Lipiodol UF is best suited for sialography; Myodil and Duroliopaque are less radiopaque. The relatively low viscosity of Duroliopaque seems to be a favorable property of this medium. In the assessment of these results, however, it should be remembered that, in vivo, the elimination of water-soluble media occurs as a result of excretion from and resorption by the salivary gland. In this experiment only the role of excretion in the elimination of contrast media could be tested. Further studies should be performed in vivo.

It should be stressed that in sialography glandular overfilling should be avoided even with the most suitable contrast media mentioned above. Other recommendations for optimum results in sialography are as follows:

The use of a water-soluble modium requires that radiographs be made as soon as possible after instil- 


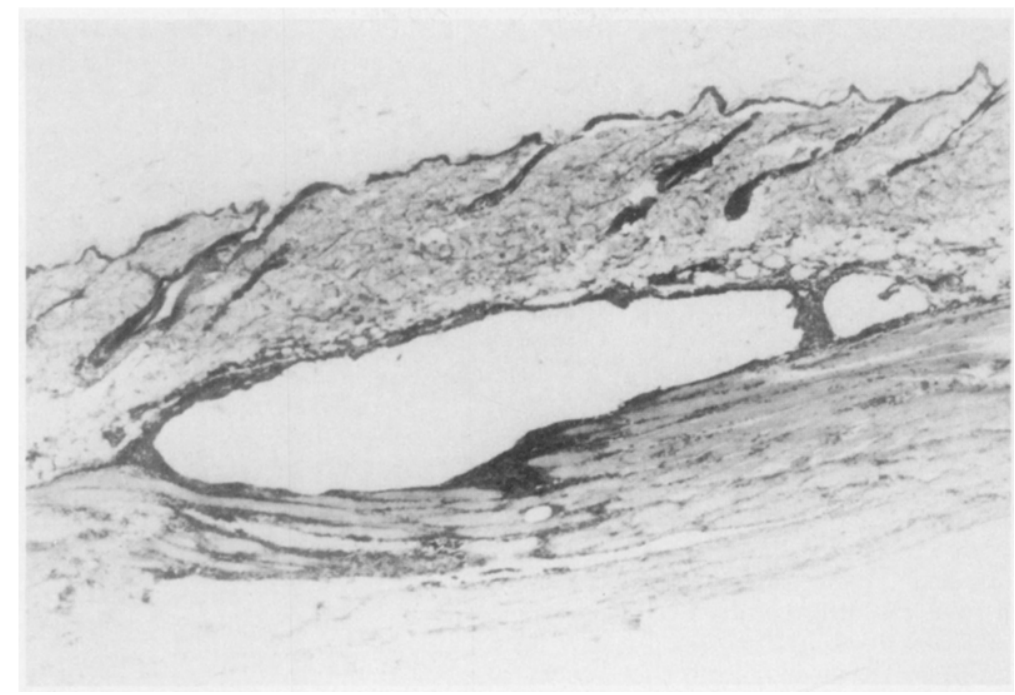

Fig. 14. Photomicrograph of rat skin tissue removed 8 days after subcutaneous application of $0.2 \mathrm{ml}$ Dionosil oily. Contrast-medium vacuoles with a moderately dense infiltrate of lymphocytes and macrophages extending between the musculature are visible in the subcutaneous tissue. (Hematoxylin and cosin stain. Magnification, $\times 15$.)

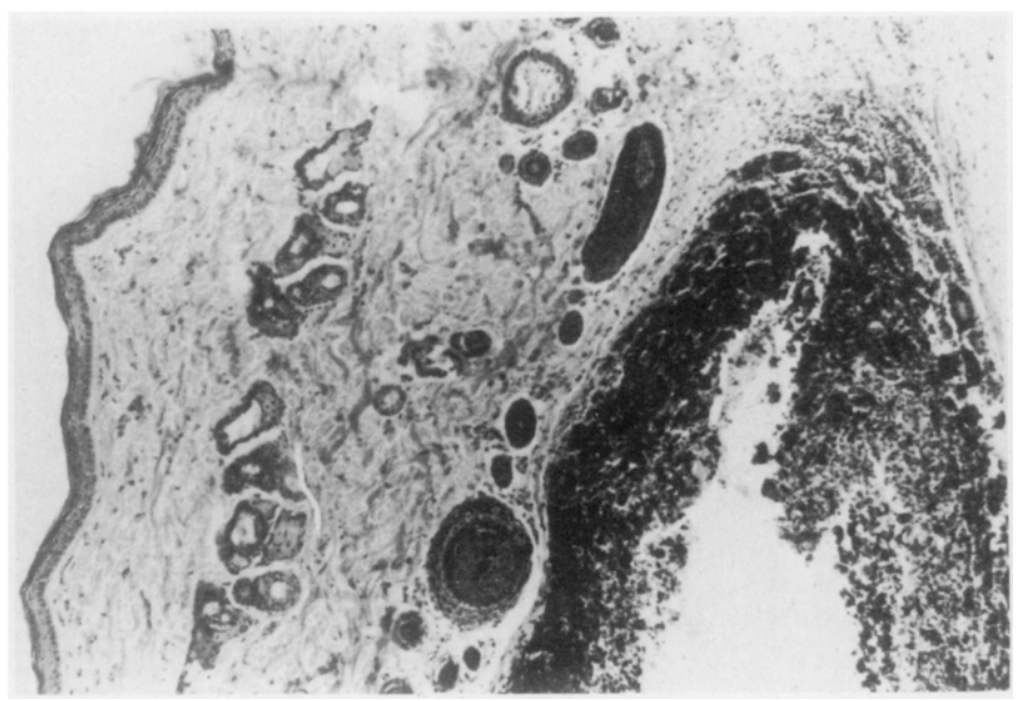

Fig. 15. Photomicrograph of rat skin tissue removed 70 days after subcutaneous application of $0.2 \mathrm{ml}$ Hytrast. Retained contrast medium, surrounded by a connective tissue capsule and some lymphocytes and macrophages, is visible in the subcutaneous tissue. (Hematoxylin and eosin stain. Magnification, $X 40$.)

lation of the medium. This is necessary to limit dilution and resorption of the medium, thus avoiding a decrease in the radiopacity of the sialogram.

Low-viscosity media make possible the study of glandular function (contrast medium evacuation studies).

The use of image intensifier fluoroscopy ${ }^{49}$ can be of value in the prevention of glandular overfilling during sialography.
Image intensifier fluoroscopy during sialography also helps to prevent the spilling of large amounts of contrast medium into the extraglandular tissues (fausse route).

The foregoing results and conclusions were based on in vitro studies and animal experiments; a prolonged clinical investigation of Conray 80, Amipaque 440, Lipiodol UF, Myodil, and Duroliopaque is desirable to determine the contrast medium best 
suited for sialography. In that clinical study, glandular overfilling should be avoided and special attention should be given to the radiopacity of the media after dilution, the evacuation of the media from the salivary glands, subjective side effects, and the quality of the sialograms.

\section{REFERENCES}

1. Brands T: Viagnose und Klinik der Erkrankungen der grossen Kopfspeicheldrüssen. München, 1972, Urban \& Schwarzenberg. pp. 44-47.

2. Mehmke $\mathbf{S}$ : Warum Seriensialographie? Radiologe 7: 152$158,1967$.

3. Ansell ( $i$ : A national survey of radiological complications: Interim report. Clin Radiol 19: 175-191, 1968.

4. Drevattne T. Stiris G: Sialography by means of a polyethylcne catheter and water soluble contrast medium (Isopaque 75\%). Br J Radiol 37: 317-321, 1964.

5. OHara $A E$ : Sialography: Past, present, and future. ('RC C Crit Rev Clin Radiol Nucl Med 4: 87-139. 1973

6. Johansen JG: Sialography with a non-ionic water-soluble contrast medium (Amipaque). Dentomaxillofac Radiol 8: $71-75.1979$.

7. Rankow RM, Polayes IM: Discase of the salivary glands. Philadelphia, 1976. W.B. Saunders Company, pp 54-97.

8. Trester PH: The development and use of contrast media in sialography. J Can Dent Assoc 34: 210-213, 1968.

9. Arnesen K: Pathological-anatomical investigations. Farmakoterapi 18: 9-12,196?.

10. Evensien A. Skalpe IO: Cell injury and cell regeneration in selective renal arteriography in rabbits. Invest Radiol 6: 290. 303, 1971.

11. Miller RE, Skucas J: Radiographic contrast agents, Baltimore. 1977. University Park Press

12. Johansen JG, Berner $A$ : Arthrography with Amipaque (metrizamide) and other contrast media. Invest Radiol I1: 534.540 .1976$.

13. Vogi K: Zur Technik und Anwendung verschiedener Kontrastmittel bei der funktionellen Sialographie. Radiol Diagn 9: $363.376,1968$

14. Carroll BA. Goldin AR: Sialography: A simplified technique. Radiology 117: 220-22!, 1975.

15. Lilly GE, et al: Radiopaque contrast mediums: Effect on dog salivary gland and subcutaneous tissues. J Oral Surg 26: $94-98,1968$

16. Mandel L, Baurmash H: Radiopayue contrast solutions for sialography. J Oral Ther Pharmacol 2: 73-80, 1965.

17. Vel-aren IW: Modern trends in diagnostic radiology (third series). London 1960, Butterworth.

18. Vitsche H, Valyi $\mathrm{E:}$ : Methylglucamine iodipamide: Contrast material for sialography. J Oral Surg 20: 220-221, 1962

19. Hollender L. Lindvall $A M$ : Sialographic technique. Dentomaxillofac Radiol 6: $31-40,1977$

20. Sheach JM: Hysterosalpinography. J Fac Radiol (I.ond) 10: 103-107. 1959.

21. Sörensen SE: Microvascular effects of roentgen contrast media. Thesis. Gothenburg. 1971.

22. Knoefel PK: Radiopaque diagnostic agents, Springfield. 1961. Charles C. Thomas.

23. Braband $H$, et al: Sialographie mit einem neuen Kontrastmittel. Roentgenopraxis 24: 45-48, 1971.

24. Herberhold C. Müller G: Sialographie mit Hytrast. Arch Klin Exp Ohr Nas Kehlkopheilk 199: 623-628, 1971.

25. Kemple B: Füllungen der Speicheldrüsen mil einem mikrokristallinen Röntgenkontrastmittel. Radiologe 10: 259-261. 1970 .

26. Greenberg SD: Experimental study of bronchographic media on lung. Arch Otolaryngol 83: 276-282, 1966.

27. I.ight IP, Oster WF: Clinical and pathological reactions to the bronchographic agent Dionosil aqueous. Am J Roentgenol 98: $468-473.1966$.
28. Cabrera $\wedge$. ct al: Crystalline inclusion pneumonia following the use of Hytrast in bronchography. $\mathrm{Am}$.J Clin Pathol 47: $154-159,1967$

29. Velson SW: el al: lurther experience with barium sulfate as a bronchographic contrist medium In I Roentgenol 92: 59) $5-614.1964$.

30. Mounts RJ, Molnar $W$ : The clinical evaluation of a new bronchographic contrast mediun. Radiology 78: 23l-233. 1962 .

31. Rayl DF: Spjut HJ: Pneumonic reaction induced by bronchographic medium. Am Rev Respir Dis 89: 503-518, 1964.

32. Brands T. Schnepper F: Zur Technik der gezielten fraktionierten Sialographie. Roentgenpraxis 20: 221-226, 1967.

33. Schult / HG: Das Röntgenbild der Kopfspeicheldrüsen. leipiig. 1969. Johann Ambrosius Barth. pp. 17-23.

34. Epsteen (M. Bendix R: Effect of non-volatile substances on salivary glands in sialography. Plast Reconstr Surg 13: 299.306. 1954.

35. Björk I I odin 11: Pulmonary changes following bronchography with Dionosil oily (animal experiments). Acta Radiol 47: $117-180.105 ?$

36. Wright $F W^{\prime}$ Aecidental injection of Dionosil into the neck during bronchography. Clin Radiol 21: 384-389, 1970.

37. Manashil GB: Sialography -A simple procedure. Med Radiogr Phologr 52: 34-42. 1976.

38. F:psteen ( 1 : Sialography. A non-irritating medium. Am J Surg 92: 60.3-605, 1956.

39. Holtgrave t: et al: Sialography with Telebrix 38: A comparative study with 1 ipiodol $\mathrm{UF}$ in the diagnosis of salivary gland diseases. Dentomaxillofac Radiol 2: 68-72, 1973

40) Felton $W 1$. The reaction of pulmonary tissue to I ipiodol I Thorac Surg 25: 530-542, 1953.

41. Fischer HW: Lymphangiography and lymphadenography with various contrast agents. Ann NY Acad Sci 78: 799-808, 1959.

42. (iuerbet $M$ : Etude pharmacologique du monoiodostéarate d'ethylc: Produit de contraste pour myélographie Therapie 21: 1219-1227, 1966.

43. Teplick JG: Total myclography with radiopaque emulsions. Radiology 90: 698-704, 1968.

44. Rubin P. at al: Physiological or secretory sialography. Ann Otol Rhinol laryngol 64: 667-688, 1955.

45. Meine FJ. Woloshin $\mathrm{HJ}$ : Radiologic diagnosis of salivary gland tumors. Radiol Clin North Am 8: 475.485, 1970

46. Cioebel $W \mathrm{M}$ In vitro comparison of sialographic agents. Oral. Si fer 43: 960-965, 1977.

47. Mason DK. Chisholm DM: Salivary glands in health and disease, Lundon, 1975, W.B. Saunders Company, p. 277.

48. Parsons PA, (jarrett JR: Movement of horseradish peroxidase in submandibular glands of dogs after ductal injection. Med Biol 55: 249-260, 1977

49. Verhoeven JW, Sanderink (FCH: Indirect radiography with the use of an image intensitiet in dentomaxillofacial radiology. Dentomaxillofac Radiol 8: 17-29, 1979.

50. Bocring (;. U al: Het genesmiddel in de tandheclkunde. I ciden. 10?7. Stafleu en Tholen. p. 413.

Reprine requests ex:

Dr. I.W. Verhoeven

University of l'trecht Dental School

Sorbonnelaan 16

$3584 \mathrm{CA}$ Utrecht, The Netherlands

\section{Appendix}

Composition of artificial saliva used in this study ${ }^{50}$ :

$\mathrm{Na}$-carboxymethylcellulose medium viscous

$10 \mathrm{~g} / 1$ 


$\begin{array}{ll}\text { Sorbitol } & 30 \\ \mathrm{KCl} & 1.2 \\ \mathrm{NaCl} & 0.855 \\ \mathrm{MgCl} \cdot 6 \mathrm{H}_{2} \mathrm{O} & 0.050 \\ \mathrm{CaCl}_{2} \cdot 2 \mathrm{H}_{2} \mathrm{O} & 0.218 \\ \mathrm{~K}_{2} \mathrm{HPO}_{4} & 0.343 \\ \text { Methylparaben } & 1 \\ \text { Aqua ad } 1,000 \mathrm{ml} & \end{array}$

During the progression of the in vitro experiments a second type of artificial saliva* became available. The most important difference from the above-

*From Prof. Dr. E. J.'s-Gravenmade, Department of Materia Technica, Subfaculty of Dentistry, University of Groningen, Groningen, The Netherlands. mentioned artificial saliva is the replacement of the viscosity factor $\mathrm{Na}$-carboxymethylcellulose medium viscous by mucin. Testing of some of the watersoluble media with this saliva resulted in slightly different values for dilution and evacuation in vitro.

Manufacturers of the investigated contrast media: Conray 80-Byk Gulden, Konstanz, West Germany. Isopaque 440, Amipaque-Nyegaard, Oslo, Norway. Urombrine 420-Dagra, Diemen/Brussels/ Lisbon/Madrid. Urografin 76\%, Endografin Schering, Berlin/Bergkamen, Germany. Hytrast, Lipiodol UF, Duroliopaque-Guerbet, Aulnay-sous-Bois, France. Dionosil oily, Myodil-Glaxo, Greenford, England. 